\title{
A Study on Construction of Low Carbon Level Evaluation Index System under Resource Constraint
}

\author{
Zhang Hang \\ School of Economics and Management of Northwest University, Xi'an, Shaanxi \\ 1535975895@qq.com
}

\begin{abstract}
Keywords: Low carbon economy; Energy saving and emission reduction; Evaluation index new system; Evaluation model; AHP
\end{abstract}

\begin{abstract}
With the constant progress of development of industrial society, the global warming caused by anthropogenic greenhouse gas emission has drawn great attention from the international society; and meanwhile, it also induces the rapid development of low carbon economic concept. At present, to promote better development of low carbon economy and to enhance the resource use efficiency constantly, we need to establish an efficient and practical low carbon level evaluation index system in condition of resource constraint to monitor the status of low carbon economy construction and development and to put the low carbon policies into practice. Only in this way, can the economic society realize sustainable development. In view of this, this paper firstly establishes the low carbon level evaluation index system by analyzing the core concept of low carbon economy; and secondly focuses on analyzing in fuzzy analytic hierarchy method; and then it performs empirical analysis on low carbon by establishing the comprehensive evaluation model and finally it puts forward the solutions.
\end{abstract}

\section{Foreword}

Energy and environment are key factors in limiting national economy and social development. To face the increasingly serious energy and environment pressure and to comply with the trend of world economic development, development of low carbon economy and implementation of energy saving and emission reduction is a long-term and arduous task. Thus, we need to establish a low carbon level evaluation index system to do further scientific evaluation on the energy saving and emission reduction condition of a nation, region, industry or an enterprise and to get to know results achieved and existing problems. And then we can sum up the experience, correct the shortcomings and take some measures to further enhance the development level of low carbon economy.

\section{Four Core Elements of Low Carbon Economy}

As for the connotation of low carbon economy, ZHOU Shengxian, the minister of the National Ministry of Environmental Protection once said: "Low carbon economy is an economic pattern based on low consumption, low emission and low pollution, and it is a great process of human society after original civilization, agriculture civilization and industrial civilization. Its essence is to enhance the resource utilization efficiency and to create a clean energy structure and its core is the conversion of technical innovation, system innovation and development concept. The development of low carbon economy is a global revolution involving production mode, life mode, values and national rights". The report of China Council for International Co-operation on Environment and Development (CCICED) indicates that: "Low carbon economy is an economic form emerging in post-industrial society. It aims to reduce the emission of greenhouse gas to a certain standard to 
prevent various nations and citizens from bad influences of climate warming and to guarantee sustainable global human settlement finally".

We can see from the above definition that no matter what we do: developing low carbon economy, controlling pollution or protecting environment, its essence is always the development. The low carbon economy must be implemented on the basis of development assurance; the specific methods and essence of development low carbon economy is to enhance resource utility efficiency and to create clean energy structure, namely energy saving and emission reduction; the ultimate goal is sustainable development, that is to say, the development of low carbon economy is taking the sustainable development of economy as the final objective; and meanwhile, the sustainability of low carbon economy itself is also one of its meanings. All in all, the four elements in developing low carbon economy are: economic and social development, energy saving, emission reduction and sustainability. Their relations can be seen in Fig. 1.

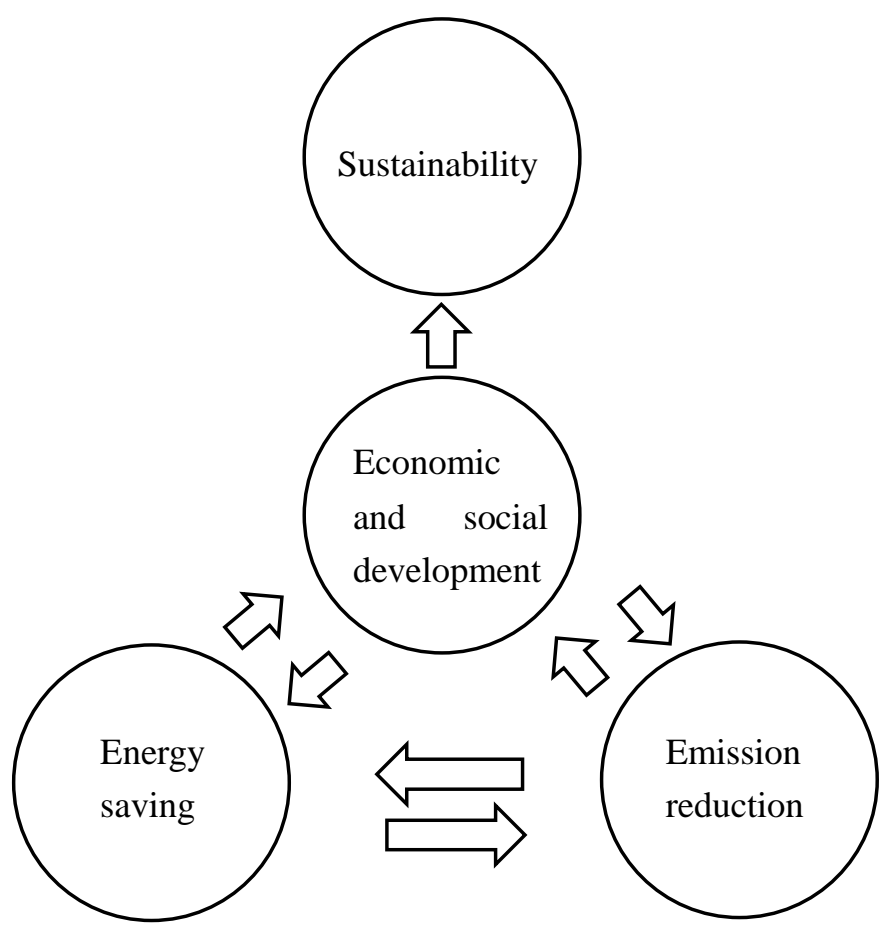

Figure 1. One Relations of four elements of low carbon economy

\section{Hierarchical Division and Contents of Low Carbon Level Evaluation Index System Based on Four Core Elements}

Based on four core elements, the paper divides the low carbon level index system into four evaluation levels: economic and social development, energy conservation, emission reduction and sustainable energy saving and emission reduction capacity. However, the low carbon level evaluation object is an important part of the main body of socialist market economy. It has various and complex levels, not only including the executive condition of energy saving and emission reduction of the nation and society and government, but also including the progress condition of energy saving and emission reduction of industries and enterprises. Therefore, the construction of energy saving and emission reduction evaluation system should not be uniform. We should take the physical situation of the specific research object, take the scientific classification as basis and apply systematic theory to create the hierarchical framework for low carbon level evaluation, and then establish the low carbon level evaluation system based on the specific condition and characteristics 
of each level. Based on the principles of accuracy, independence, completeness, consistency, practicability and acceptability, the general evaluation index system we constructed is shown as Table 1.

Table 1 Low carbon level evaluation index system and its weight

\begin{tabular}{|c|c|c|c|c|}
\hline $\begin{array}{l}\text { Target } \\
\text { Level }\end{array}$ & $\begin{array}{c}\text { Rule } \\
\text { Hierarchy } \\
1\end{array}$ & $\begin{array}{c}\text { Rule } \\
\text { Hierarchy } 2\end{array}$ & Index Level & $\begin{array}{l}\text { Total } \\
\text { Weight in } \\
\text { Fuzzy } \\
\text { Analytic } \\
\text { Hierarchy } \\
\text { Method }\end{array}$ \\
\hline \multirow{9}{*}{$\begin{array}{l}\text { Low } \\
\text { Carbon } \\
\text { Level } \\
\text { Evaluation } \\
\text { Index } \\
\text { System }\end{array}$} & \multirow{2}{*}{$\begin{array}{l}\text { Economic } \\
\text { and social } \\
\text { developme } \\
\text { nt index } \\
\text { A1 }(0.121)\end{array}$} & $\begin{array}{l}\text { Economic } \\
\text { development } \\
\text { B1 }(0.837)\end{array}$ & $\begin{array}{l}\text { GDP gross C1 }(0.633) \\
\text { Per Capita GDP C } 2(0.260) \\
\text { GDP proportion of the tertiary industry C3 } \\
(0.107)\end{array}$ & $\begin{array}{l}0.06433 \\
0.02652 \\
0.01077\end{array}$ \\
\hline & & $\begin{array}{l}\text { Social } \\
\text { development } \\
\text { B2 }(0.163)\end{array}$ & $\begin{array}{l}\text { Urbanization rate } \mathrm{C} 1(0.776) \\
\text { Forest coverage rate } \mathrm{C} 2(0.155) \\
\text { Urban per capita public green areas } \mathrm{C} 3 \\
(0.069)\end{array}$ & $\begin{array}{l}0.01583 \\
0.00316 \\
0.00139\end{array}$ \\
\hline & \multirow[t]{2}{*}{$\begin{array}{l}\text { Emission } \\
\text { reduction } \\
\text { index A2 } \\
(0.263)\end{array}$} & $\begin{array}{l}\text { Pollution } \\
\text { intensity B1 } \\
(0.837)\end{array}$ & $\begin{array}{l}\text { CO2 emission load of unit GDP C1 }(0.557) \\
\text { SO2 emission load of unit GDP C2 }(0.263) \\
\text { COD emission load of unit GDP C3 } \\
(0.122) \\
\text { Ammonia nitrogen emission load of unit } \\
\text { GDP C4 }(0.057)\end{array}$ & $\begin{array}{l}0.01125 \\
0.05762 \\
0.02673 \\
0.01249\end{array}$ \\
\hline & & $\begin{array}{l}\text { Pollution } \\
\text { abatement B2 } \\
(0.163)\end{array}$ & $\begin{array}{l}\text { Industrial SO2 removal rate } \mathrm{C} 1(0.833) \\
\text { Municipal solid waste innocent treatment } \\
\text { rate } \mathrm{C} 2(0.167)\end{array}$ & $\begin{array}{l}0.03659 \\
0.00733\end{array}$ \\
\hline & \multirow[t]{2}{*}{$\begin{array}{l}\text { Energy } \\
\text { saving } \\
\text { index A3 } \\
(0.559)\end{array}$} & $\begin{array}{l}\text { Energy } \\
\text { efficiency B1 } \\
(0.874)\end{array}$ & $\begin{array}{l}\text { Energy consumption of unit GDP C1 } \\
(0.833) \\
\text { Energy consumption of unit industrial } \\
\text { added value C2 }(0.167)\end{array}$ & $\begin{array}{l}0.40671 \\
0.08154\end{array}$ \\
\hline & & $\begin{array}{l}\text { Energy } \\
\text { structure B2 } \\
(0.126)\end{array}$ & $\begin{array}{l}\text { Total energy consumed } \mathrm{C} 1(0.167) \\
\text { Coal consumption ratio of energy } \\
\text { consumption } \mathrm{C} 2(0.833)\end{array}$ & $\begin{array}{l}0.01165 \\
0.05810\end{array}$ \\
\hline & \multirow{3}{*}{$\begin{array}{l}\text { Sustainabl } \\
\text { e energy } \\
\text { saving and } \\
\text { emission } \\
\text { reduction } \\
\text { capacity } \\
\text { index A4 } \\
(0.057)\end{array}$} & $\begin{array}{l}\text { Policy setting } \\
\text { and executive } \\
\text { level B1 } \\
(0.428)\end{array}$ & $\begin{array}{l}\text { Energy saving policy setting and publicity } \\
\text { level C1 }(0.76) \\
\text { Executive strength of energy saving and } \\
\text { emission reduction policy C } 2(0.24)\end{array}$ & $\begin{array}{l}0.01834 \\
0.00611\end{array}$ \\
\hline & & $\begin{array}{l}\text { Organization } \\
\text { structure } \\
\text { construction } \\
\text { level B2 } \\
(0.143)\end{array}$ & $\begin{array}{l}\text { Energy saving and emission reduction } \\
\text { institution setting status C1 (0.76) } \\
\text { Energy saving and emission reduction goal } \\
\text { decomposition and implementation and } \\
\text { status of performance assessment rewards } \\
\text { and punishment mechanism C2 }(0.24)\end{array}$ & $\begin{array}{l}0.00607 \\
0.00202\end{array}$ \\
\hline & & $\begin{array}{l}\text { Science- } \\
\text { technology } \\
\text { support } \\
\text { ability B3 } \\
(0.429)\end{array}$ & $\begin{array}{l}\text { R\&D input proportion of GDP C1 }(0.790) \\
\text { High technology output value proportion } \\
\text { of total industrial output value C2 }(0.130) \\
\text { Higher educational population rate C3 } \\
(0.080)\end{array}$ & $\begin{array}{l}0.01932 \\
0.00325 \\
0.00188\end{array}$ \\
\hline
\end{tabular}




\section{Construction of Comprehensive Evaluation Model in Fuzzy Hierarchy Evaluation Method}

The fuzzy hierarchy evaluation method is composed of two parts: fuzzy comprehensive evaluation and analytical hierarchy process (AHP). It means confirming sub-goal and various index weight through analytical hierarchy process and evaluating energy saving and emission reduction by fuzzy comprehensive evaluation method.

As for the construction of fuzzy-AHP comprehensive evaluation model, we can see from the single factor evaluation matrix $X$ that: Line $I(i=1,2, \ldots, n)$ of $X$ reflects the degree of membership of the ith element impact evaluation object to various evaluation sets; the Row $\mathrm{j}(\mathrm{j}=1,2, \ldots, \mathrm{m})$ reflects the degree of membership of the jth element impact evaluation object to the jth evaluation set elements. When the weight set $\mathrm{W}$ and single factor evaluation matrix $\mathrm{X}$ are given, we can perform the comprehensive evaluation by fuzzy transformation, and we can get the fuzzy synthetic evaluation model, just shown as Formula (1):

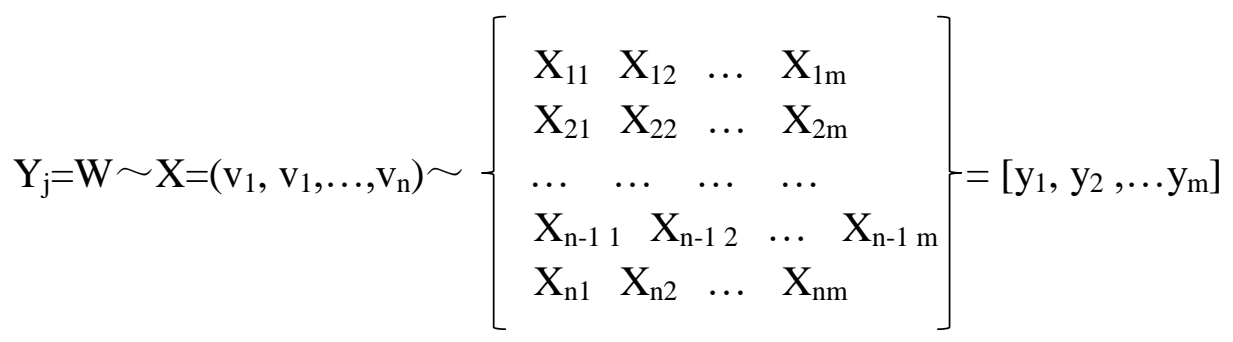

In Formula 1, “ ”means some compositional operation; $\mathrm{Yj}(\mathrm{j}=1,2, \ldots, \mathrm{m})$ is called fuzzy comprehensive evaluation index. Y $\mathrm{j}$ refers to the degree of membership of the evaluation object to the $\mathrm{j}$ elements in the evaluation set when the influence of all factors is taken into overall consideration. Due to different fuzzy compositional operations " $\sim$ ", there are four different calculation models for fuzzy comprehensive evaluation methods generally. We select the product summation type $\mathrm{M}(\times,+)$ in the paper, just shown as Formula (2):

$Y_{j}=\sum_{i=1}^{n}\left(v_{i} x_{i j}\right)_{(j=1,2, \ldots, m)}$

Just shown as Formula 2, the model multiplies vi by xij firstly, and then does the summation operation; its value is the element $\mathrm{Yj}$ in the evaluation set; it not only considers the influence of all factors, but also reserves all information of single factor evaluation, which fits the condition of overall index. The hierarchical energy saving and emission reduction evaluation established in the paper also adopts this method.

We can get the evaluation index $\mathrm{Yj}(\mathrm{j}=1,2, \ldots, \mathrm{m})$ through the above operation. Generally, the evaluation result of the evaluation object should be confirmed based on the maximum membership degree method. Based on the maximum membership degree principle, the $x i$ in the evaluation set corresponding to the largest bi is the result of the comprehensive evaluation.

\section{Empirical Analysis of Low Carbon Level Evaluation}

Empirical analysis is the process of actual survey of evaluation index designed above and established model, and is the key factor to judge the rationality of the energy saving and emission reduction evaluation index system. Next, I will do the empirical analysis by taking China macroeconomic data in 2014 as an example. Firstly, use the AHP method to confirm energy saving 
and emission reduction evaluation index weight; that is to say: take the method of scoring by expert to compare and grade between any two means in the 23 indexes in the above evaluation index system (shown as Table 1) in 1- 9 scale method, and get the overall ranking levels and energy saving and emission reduction evaluation index weight finally; and then we can get the evaluation index total weight (shown as Table 1) after the measurement of fuzzy evaluation method.

We can obtain the fuzzy comprehensive evaluation index $\mathrm{C}$ based on the weight set $\mathrm{W}$ confirmed in AHP method and fuzzy evaluation matrix $\mathrm{R}$ confirmed by fuzzy mathematics subordinating degree function method:

$$
Y_{j}=W \sim X=\left(v_{1}, v_{1}, \ldots, v_{n}\right) \sim\left[\begin{array}{cccc}
X_{11} & X_{12} & \ldots & X_{1 m} \\
X_{21} & X_{22} & \ldots & X_{2 m} \\
\ldots & \ldots & \ldots & \ldots \\
X_{n-1} & X_{n-1} & \ldots & X_{n-1} \\
X_{n 1} & X_{n 2} & \ldots & X_{n m}
\end{array}\right]=[0.2654,0.4767,0.2355,0.0224]
$$

As $0.2654+0.4767+0.2366+0.0213=1$, the fuzzy hierarchy comprehensive evaluation result is a normalization result. Thus we can get that $26.54 \%$ thinks that the result of China energy saving and emission reduction is great; $47.67 \%$ thinks that result of China energy saving and emission reduction is good; $23.55 \%$ thinks it is in mediate level and $2.24 \%$ thinks it is bad. Based on the maximum degree of membership, the level corresponding to the largest number 0.4767 is good; that is to say, the result of China energy saving and emission reduction is good. The evaluation result conforms to the practical situation, so the model fitting status is good.

\section{Conclusion}

We can see from the above analysis that the result of China energy saving and emission reduction is good after we do the construction of energy saving and emission reduction evaluation system based on fuzzy hierarchy method and empirical analysis. But due to the phase characteristics of China economic development, the development level of low carbon economy is still low. Hence, I put forward several solutions in the paper: on one hand, China must stick to the strategy of sustainable development, implement energy saving and emission reduction on the premise of social and economic development and guarantee the sustainability of energy saving and emission reduction; one the other hand, China should introduce new technology subsidy policy, complete laws and regulations about intellectual property and promote scientific innovation; at the same time, China should accelerate industrial restructuring and optimization to provide power for sustainable, rapid and smooth development of economy, to create favorable conditions, to realize the goal of energy saving and emission reduction and to boost the sustainable development of low carbon economy.

\section{References}

[1] ZUO Qiting, WANG Li; Evaluation Method and Application of Resource-conserving Society [J]; Resource Science; 2008 (3): 409- 413

[2] WANG Yanpeng; China Energy Conservation and Emission Reduction Index System Research [J]; Coal Economic Research; 2009 (2): 31 - 32 
[3] SONG Malin, YANG Jie, SUN Xin; Domestic Energy Conservation and Emission Reduction Evaluation Research in Various Regions [J]; Resource Development and Market; 2008 (1): 31 33

[4] WU Qi; China Provincial Energy Efficiency Evaluation Research [D]; Dalian University of Technology; 2010

[5] ZHANG Liangqiang, LIU Xiangxu; Research on Resource-conserving Society Evaluation Index System Based on BSC [J]; Study in Science of Science; 2008 (1): 150- 155

[6] MI Qiang, MI Juan; Primary Investigation on China Energy Saving and Cost Reducing Index System [J]; Ecological Economy; 2010 (2): 58- 61

[7] FU Jiafeng, ZHUANG Guiyang; GAO Qingxian; Concept Identification of Low Carbon Economy and Construction of Evaluation Index System [J]; Chinese Population·Resource and Environment; 2010: 20- 8

[8] WANG Feng, WU Lihua, YANG Chao; Driving Factor Research of Carbon Emission Increase in China Economic Development [J]; Economic Research; 2010 (02)

[9] GUO Yin, WANG Jiemin; Enlightenment on China of International Low Carbon Economic Development Experience [J]; Revolution and Strategy; 2009 (10)

[10]WANG Bin; Enlightenment on China of Practice of Low Carbon Economy Transition of Developed Countries [D]; Jilin University; 2010 